nost, a predstavljen je i projekt pod nazivom Arhivski fond Rudija Supeka.

Drugog dana kongresa novi je predsjednik održao i inauguracijski govor u kojem je istaknuo pozitivne aspekte rada prethodnog predsjedništva i konsolidaciju društva u prethodnome razdoblju te naglasio potrebu kontinuiteta, ali i istaknuo područja na kojima hrvatska sociologija mora nastaviti ili pojačati angažman, počevši od vidljivosti sociologije u javnosti, rada unutar sekcija HSD-a (čije napredovanje $\mathrm{u}$ proteklim godinama ipak nije bilo neprimijećeno) i internacionalizacije hrvatske sociologije, kao i školovanja novih socioloških generacija na svim trima razinama studija.

Kako je ovaj prikaz započet razmatranjima o promjenama u hrvatskoj sociologiji, prikladno bi bilo da s njima i završi. Ono što je bilo osobito vidljivo, a i istaknuto u programskoj knjižici, velik je broj istraživačica i istraživača mlađe generacije. Nezanemariv dio radova, pa i onih u plenarnim sesijama, predstavili su sociolozi i sociologinje koji pohađaju poslijediplomski studij ili su netom doktorirali, odnosno naslućuje se sociološki »novi val«. Jedan od najvidljivijih učinaka nove generacije svakako je i metodološki pomak, a tiče se ponajprije snažnog ulaza kvalitativnih metoda u hrvatsku sociologiju. Ovaj je kongres donio velik broj radova utemeljenih na kvalitativnoj sociologiji, što, uz vrlo aktivan rad novoosnovane HSD-ove sekcije za kvalitativne metode istraživanja te nedavnu riječku međunarodnu konferenciju posvećenu kvalitativnoj metodologiji u sociologiji, govori o novim trendovima koji su, uostalom, apostrofirani i u uvodnoj riječi. Ova svakako dobrodošla situacija možda je donekle zasjenjena time što se kvalitativna metodologija, sudeći po rodnom sastavu onih koji se njome bave ili barem čiji su radovi prošli selekciju, afirmira gotovo kao »žensko pismo« hrvatske sociologije.

Kongres Hrvatskoga sociološkog društva iznio je na vidjelo, čini se, neke uistinu pozitivne trendove, a vjerujemo da će ih novo vodstvo poduprijeti i tako pridonijeti daljnjem razvoju hrvatske sociologije.

Sven Marcelić Odjel za sociologiju, Sveučilište u Zadru

DOI: $10.5613 /$ rzs.41.1.9

\section{Međunarodna konferencija „New challenges and methodological innovations in European media audience research»}

Zagreb, 7-9. travnja 2011.

Transformacija tradicionalnih medijskih sustava i njihova konvergencija $u$ novom, digitalnom medijskom okolišu dovela je do promjene u načinima i oblicima na koje publika s njima i međusobno komunicira. Društvene i kulturne promjene, prateći tehnološ$\mathrm{ku}$ dimenziju transformacije, dovele su i do primjetnih promjena u praksi medijske publike. Proces koji se prije temeljio na potrazi za informacijama sada se prebacio na intenzivniji komunikacijski aspekt gdje publika više nije 
samo ona koja isključivo »čita« medijske sadržaje, nego i aktivno sudjeluje u proizvodnji, ali i znatno intenzivnijoj interakciji s drugim korisnicima. Promjena tehnoloških paradigmi, ili barem njihovo umnožavanje, predstavlja za područja medijskih studija iznimno zahtjevan metodološki izazov na koji treba odgovoriti inovacijama, a kako bi se adekvatnije i preciznije obuhvatila iskustva i prakse »multiplatformske« publike. Inzistiranje na arhaičnim metodološkim pristupima i teorijskim okvirima za posljedicu bi moglo imati slabiju ili neprecizniju empirijsku materiju kad su medijske publike i novi medijski sustavi posrijedi.

Upravo je zbog takvih razloga trodnevna konferencija organizirana pod pokroviteljstvom COST mreže i u sklopu projekta »Transforming Audiences, Transforming Societies«, a uz potporu Hrvatskih studija Sveučilišta u Zagrebu, okupila trenutačno najproduktivnija europska istraživačka imena (Sonia Livingstone, Dafna Lemish, Kristen Drotner, Klaus Bruhn Jensen, Peter Dahlgren i mnogi drugi) kako bi se predstavile raspravile mogućnosti novih načina i pristupa $\mathrm{u}$ istraživanju medijskih publika. Unutar tri dana raspravljalo se u nekoliko tematskih blokova. Prvoga su dana organizirane panel-rasprave unutar kojih su se problematizirala pitanja istraživanja i implementacije programa medijske pismenosti, uz naglasak na suradnju s neakademskim sektorom. Tom su prigodom svoja viđenja tog procesa iznijeli Paolo Celot, glavni tajnik EAVIa (European Association for Viewers' Interests), Susanne Ding, predsjednica Opće uprave za obrazovanje i kulturu Europske komisije, Kristen Drotner, profesorica sa Sveučilišta Južne Danske, i Jane Rumble, predsjednica skupine za medijsku pismenost pri Ofcom centru za medijska istraživanja. Izlaganja su se fokusirala na mogućnost suradnje, predstavljajući istodobno i istraživanja koja su se bavila analizama različitih dimenzija medijske pismenosti. Rasprava se kretala oko problema ideologizacije programa medijske pismenosti uz napomenu kako loše osmišljena strategija može dovesti do kulturnih isključivanja nauštrb pretpostavljenih programskih prijedloga i ideja.

Drugi dio panel-rasprave, kojom je predsjedao Guy Starkey, ponudio je slična izlaganja s izuzetkom neakademskoga istraživačkog projekta Simone Sbarbaro, voditeljice istraživačkog odjela MTV International. Prema prezentiranim rezultatima projekta »Youthopia«, prosječni gledatelji MTV-a značajno odstupaju od stereotipnih predodžbi koje o njima postoje u javnosti kao o pasivnim, lijenim egocentricima. Sbarbaro je naglasila kako je uspješnost projekta upravo bila u činjenici što je postignut $\mathrm{u}$ suradnji $\mathrm{s}$ akademskim sektorom. Zaključna razmatranja obaju panela odnosila su se na potrebu jače suradnje akademskog i neakademskog sektora, ali sa snažnim implikacijama za etičke probleme koji se u tom procesu mogu pojaviti. Potreba za suradnjom stoji u kvaliteti izrade programskih planova medijske pismenosti, kao i boljom komunikacijom između tih dvaju sektora u svrhu osvještavanja važnosti reguliranja pojedinih sadržajnih elemenata njihovih programa.

Drugi dan konferencije započeo je uvodnim izlaganjem Uwea Hasebrinka na temu izazova i potreba za metodološkim inovacijama u području istraživanja medijskih publika. Tom prilikom 
Hasebrink je naglasio kako se, prema najnovijim istraživanjima, suvremeni korisnik u potrazi za informacijama služi višestrukim medijskim platformama, ali i da vrsta medijskih platformi ovisi i o izvorima medijskih potreba pojedinca ili publike. Hasebrink tako navodi razliku, ali i vezu, između četiriju predloženih koncepata korisnika/ publike (pojedinac, zatvorene zajednice, interesne skupine i masovna publika) i njima kompatibilnih četiriju vrsta medijskih platformi ili tipova medija (individualizirani servisi, društvene mreže, tematski televizijski kanali i specijalizirani časopisi te opći televizijski kanali i časopisi). Takav odnos onda dovodi i do stvaranja onoga što on naziva "medijskim repertoarom « (media repertoire), a koji je uvjetovan promjenama u načinu na koji publika traži i dolazi do informacija. Te promjene, uvjetovane jačanjem procesa individualizacije i kulturne fragmentacije, učinile su medijske publike »pokretnom metom« za koje je potrebno ponovno promisliti načine metodoloških pristupa. Na kraju je Hasebrink pozvao i na potrebu preciznijeg promišljanja i definiranja metodoloških implikacija koje izlaze iz načina na koji se opisuje suvremena medijska publika. Inzistiranje isključivo na aktivnoj ili pasivnoj dimenziji nije dovoljno te zaključuje kako se, s obzirom na pristup i korištenje medijskih repertoara, može govoriti o kategorijama potrošača, korisnika prava i na kraju aktivnog građanina. Svaka od ovih kategorija ima svoje posebne dimenzije iz kojih se mogu izvlačiti pretpostavke za metodološku orijentaciju. Konačan rezultat trebao bi biti preciznija akumulacija empirijskog materijala i bolji uvid u dinamiku načina korištenja medija.
Drugo uvodno izlaganje održao je Peter Dahlgren, gdje se pokušalo povezati tematsko pitanje konferencije s pitanjima (političkih) participacijskih praksi u online kontekstu. Prema Dahlgrenu, novi medijski okoliš posjeduje znatno fleksibilnije tehnološke karakteristike bitne za participacijske prakse korisnika, ali i naglašava važnost društvene kontekstualizacije demokratskih praksi kako bi se mijenjajući odnosi znatno bolje razumjeli. Iz ovih elemenata Dahlgren predlaže potrebu za konceptualizacijom "građanskih kontingencija« (civic contingencies) razvrstavajući ih prema parametrima njihovih a) smjernica, b) modaliteta, c) predispozicija, d) socijabilnosti i e) vidljivosti. Takav iznimno kompleksan, ali razumljiv analitički model osigurava precizniji uvid u dinamiku i ishod participacijskih praksi $\mathrm{u}$ online kontekstu, a koje, prema njegovu tumačenju stvari, idu sve više u područje zatvaranja u habitus »solo sfere« javnog angažmana. Važnost tog izlaganja je u pokušaju da se multiteorijskim i multidisciplinarnim pristupom pragmatički riješe problemi oko razumijevanja dinamike i ishoda korištenja digitalnih tehnologija u svrhu participacijskih praksi, a što onda može pronaći i svoju primjenjivost u nastojanjima da se inovativno odgovori na metodološke izazove $\mathrm{u}$ istraživanjima medijske publike.

Sesije su se s obzirom na dvije glavne teme, medijsku pismenost te probleme i perspektive metodologije istraživanja medijske publike, podijelile uzduž nekoliko osnovnih parametara. S jedne se strane išlo na pokušaj povezivanja i promišljanja novih metodologija u kontekstu tehnoloških promjena, a s druge su se metodološke implikacije 
tražile u promijenjenom sociokulturnom okolišu. Primjerice, »migracije« publika u online kontekst, u kojem se, osim novih medijskih platformi, pojavljuju i remedijalizirani oblici tradicionalnih medijskih oblika, zahtijevaju brzinu i preciznost u definiranju i implementaciji različitih istraživačkih instrumenata $\mathrm{i}$ alata. I dok je web 1.0 bio relativno statičan i imao znatno manje vidljive razine interaktivnosti i samostalnosti korisnika pri obradi i odabiru podataka, web 2.0 već unutar svoje specifične tehnološke arhitekture nudi istraživačima mogućnosti za bolje razumijevanje i mapiranje korisničkih praksi jer se promijenila i narav i intenzitet komunikacije. U Hastallovu i Sukallovu izlaganju predstavljeni su većinom besplatni softveri poput API programa, Google alertsa i RSS readera, a koji pružaju mogućnost brze i jednostavne akumulacije podataka potrebnih za kvantitativnu i kvalitativnu analizu sadržaja. Osim novinskih članaka, spomenuti programi mogu biti jako korisni i pri analizi komentara korisnika blogova, foruma i različitih društvenih mreža pa tako otvaraju mogućnost uvida u modele recepcije globaliziranih medijskih materijala. Slične pretpostavke vrijede i za analizu umreženosti i distribucije informacija korisnika Youtube servisa gdje se s pomoću web 2.0 generiranih alata mogu dobiti podatci o načinima komunikacije na takvoj platformi. Razmatranje načina i uvjeta u kojima dolazi do promjena u ponašanju publike pokušalo se metodološki pratiti na nekoliko različitih istraživačkih primjera. Göran Bolin tako navodi kako je od iznimne važnosti u međupovezanom medijskom okolišu (cross-media environment) koristiti ne samo analize zasnovane na tehnološkom kontekstu medijskog korištenja, nego da se potrebno osloniti i na tekstualne analize Barthesova tipa uz mapiranje tehnoloških hijerarhija recepcije kao i tekstualnih hijerarhija koje ih prate. Valjalo bi spomenuti i izlaganje Guya Starkeya o revitalizaciji radija kao medija i njegovu novom životu u divergentnom medijskom kontekstu te ono Paule Cordeiro o simbiozi društvene mreže facebook i radija.

Promišljanje odnosa sociokulturnih promjena i sociokulturnog konteksta i uloge tih elemenata $u$ promjenama $u$ obrascima ponašanja medijske publike, svelo se na nekoliko tema i perspektiva. Dafna Lemish je govorila o važnosti prepoznavanja različitih praksi i medijskog iskustva djece koja pripadaju etničkim manjinama, dok je José Carlos Sendín Gutiérrez problematizirao načine na koje se percipiraju imigrantske zajednice među španjolskim studentima u odnosu na vrste medijskog okoliša iz kojih se informacije o imigrantima dobivaju. O odnosu medija i obitelji održano je nekoliko izlaganja gdje se osobito zanimljivim pokazalo istraživanje Katje Mihajlove i Mihaila Mirčeva o utjecaju medija na transformaciju tradicionalne bugarske obitelji. S obzirom na to da je konferencija zamišljena kao multidisciplinarna obrada tekućih metodoloških problema, socioloških pristupa nije manjkalo, iako su u nekim elementima bili nedovoljno teorijski operacionalizirani. Klaus Bruhn Jensen je, primjerice, učestalo inzistirao na potrebi preciznih definicija elementarne terminologije kad su posrijedi novi medijski oblici (poput »društvenih medija«/social media/) jer se iz nejasnih kategorija onda mogu vrlo lako napraviti i metodološke pogrješke. Izlaganja koja su se bavila 
problemom akumulacije društvenog kapitala putem digitalnih mreža (Damásio i Jensen) ponudila su zanimljive spoznaje o načinima na koje se taj resurs akumulira, ali opet s pomalo nejasnim epistemološkim pretpostavkama prema kojima se ušlo u istraživački proces.

Gledajući isključivo iz metodološke perspektive, konferencija je ponudila uvid u trendove koji inzistiraju na multimetodskim i multimetodološkim pristupima kombinirajući sve - od tehnike upitnika, do promatranja i intervjua. Metodološke inovacije bile su najvidljivije $\mathrm{u}$ iskorištavanju tehničkih aspekata novih medijskih platformi (poput weba 2.0) dok se one teorijske zbog epistemološke kompleksnosti još trebaju dodatno razrađivati i raspravljati. Poziv je, u svakom slučaju, usmjeren prema intenzivnijoj interdisciplinarnoj suradnji, ali i suradnji $\mathrm{s}$ neakademskim sektorom u cilju adekvatnijeg praćenja programa medijske pismenosti. Takav je događaj, osim indikatora stanja istraživačkih pristupa u europskom kontekstu, i dobar materijal za usporedbu s hrvatskom ostavštinom medijskih istraživanja koja i teorijski i metodološki znatno zaostaje za primjerima i tendencijama razvoja izloženim u konferencijskom programu.

Krešimir Krolo Odjel za sociologiju, Sveučilište u Zadru 